\title{
Genetic Diversity and Connectivity of Sea Urchin Tripneustes gratilla in Region Surrounding Cenderawasih Bay, Papua-Indonesia and Indo-Pacific
}

\author{
Abdul Hamid A. Toha ${ }^{1 *}$, Ambariyanto Ambariyanto ${ }^{2}$, Widodo
L. N. Aminin ${ }^{4}$
${ }^{1}$ Fisheries Department, University of Papua, Manokwari, Indonesia \\ ${ }^{2}$ Department of Marine Science, University of Diponegoro, Semarang, Indonesia \\ ${ }^{3}$ Biology Department, Faculty of Mathematics and Natural Sciences, Brawijaya University, Malang, Indonesia \\ ${ }^{4}$ Chemistry Department, University of Diponegoro, Semarang, Indonesia
}

\section{ARTICLE INFO}

Article history:

Received November 18, 2020

Received in revised form October 7, 2021

Accepted October 21, 2021

\section{KEYWORDS:}

T. gratilla,

mtDNA,

COl gene,

Cenderawasih Bay,

genetic variation,

gene flow

\begin{abstract}
Cenderawasih Bay has extremely high biodiversity with an enormous amount of endemic species due to geography isolation. Tripneustes gratilla is one of the species that is abundant in the bay. The species has ecological value that is suitable for bio-indicators of the environmental condition. Since the Bay relatively isolated area, then we examined the impact of the geographical conditions on genetic diversity and connectivity of Tripneustes gratilla among populations in the region surrounding Cenderawasih Bay based on the mitochondrial cytochrome c-oxidase-1 gene. Results of the study showed that genetic variation of the species within the population is high; despite the genetic variation among populations was low. The data suggested that the entire population of $T$. gratilla were closed connected, homogeneous, and shared polymorphic profile. Then we assumed the gene flow occurred for a long time among populations without geographical barriers. This information is a warrant to develop an effective strategy to maintain biodiversity in the Cenderawasih Bay.
\end{abstract}

\section{Introduction}

Cenderawasih Bay is coral ecoregion in PapuaIndonesia, which has extremely high biodiversity and an enormous amount of endemic species (Veron et al. 2009; Starger et al. 2015). Over 50 different species of marine organisms have been found in the Cendrawasih Bay (Carpenter et al. 2011). The bay was isolated since 14 million years ago that facilitated evolution and developing endemic species (Allen and Erdmann 2008; Allen and Erdmann 2009; Alonso et al. 2011). The condition caused some species viz. Mantis shrimp and starfish were isolated in the bay (Barber et al. 2006; Crandall et al. 2008). Sea urchin found evenly distributed in the Cenderawasih bay (Toha et al. 2012, 2015). Then we anticipated that the existence of sea urchin in the bay was also isolated and has low genetic diversity.

\footnotetext{
* Corresponding Author

E-mail Address: h.toha@unipa.ac.id
}

Tripneustes gratilla is one of over 1,000 described species of sea urchins (WorRMS 2020) that is widely distributed (Toha et al. 2017; Kroh and Mooi 2019, 2020). The habitat ranges from Pacific to African coast of the Indian Ocean, including Indonesia (Toha et al. 2012; Lawrence and Agatsuma 2013; Wainwright et al. 2013; Parvez et al. 2018; Wainwright et al. 2019). The T. gratilla has economic and ecological value (Casilagan et al. 2013; Brink et al. 2019, Onomu et al. 2020; Nane and Paramata 2020) that warrant for use of bio-indicators of marine environmental conditions. Then understanding the genetic diversity of the species is paramount information to promote long-term sustainable management (Toha et al. 2014) in Cenderawasih Bay. Since the bay relatively isolated area, then we examined the impact of the geographical conditions that led to isolation of $T$. gratilla in the region.

Lessios et al. (2003) and Liggins et al. (2014) examined phylogeography and genetic patterns of $T$. gratilla in the Indo-Pacific region based on nucleotide 
sequence of the mitochondrial cytochrome c-oxidase-1 (COI mtDNA). They reported that $T$. gratilla were closed connected, homogeneous, and shared polymorphic profile. Meanwhile, in Indonesia, the population genetic of $T$. gratilla were revealed as evidence of genetically distinct clusters and structure based on microsatellite loci (Wainwright et al. 2019). However, $T$. gratilla remains genetically uncharacterised in Cenderawasih Bay. In the present study, we determined the genetic diversity and connectivity among populations of $T$. gratilla in the area surrounding Cenderawasih Bay based on the COI gene sequences. We also compared the data from this region with other the Indo-Pacific region to examine the impact of the geographical condition to the broader region.

\section{Materials and Methods}

\subsection{Sampling and DNA Sequencing}

T. gratilla was collected from Cenderawasih Bay, i.e. Wasior (3 samples), Nabire (11 samples) and Yapen or Serui (11 samples). We also collected samples from the out region of Cenderawasih Bay, such as Manokwari (34 specimens) and Biak (17 specimens). Sequences from GenBank AY205373455 (Lessios et al. 2003), JX661089-167 (Casilagan 2012), KF012802-824 (Liggins et al. 2014) were also used to complement our 76 sequences of $T$. gratilla from five locations (Figure 1). The tube feet samples were preserved in 95\% ethanol and stored at room temperature until to be used for genomic DNA extraction. The Genomic DNA were extracted from tube feet tissue using Chelex (Walsh et al. 2018). The CO1 gene was amplified using primers Trip2F (5'CCTGCAGGAGGAGGAGAYCC3') (Jacobs et al. 1988) and C01TR1 (5'GGCATTCCAGCTAGTCCTARAA3') (Lessios et al. 2003). Polymerase chain reaction (PCR) was conducted with thermocycling parameters $95^{\circ} \mathrm{C}$ for $30 \mathrm{sec}, 52^{\circ} \mathrm{C}$ for $30 \mathrm{sec}$, and $72^{\circ} \mathrm{C}$ for $30 \mathrm{sec}$, for 38 cycles. Five microliters of double-stranded PCR fragments were purified by adding 0.5 units of shrimp alkaline phosphatase, and five units of exonuclease, then incubating at $37^{\circ} \mathrm{C}$ for $30 \mathrm{~min}$ and $80^{\circ} \mathrm{C}$ for 15 min. The cleaned PCR fragments were sequenced on an ABI 377 automated sequencer using BigDye (Applied Biosystems, Foster City, CA) terminator chemistry. The forward and reverse sequences were proofread in Sequencher (Gene Codes Corp., Ann Arbor, MI).

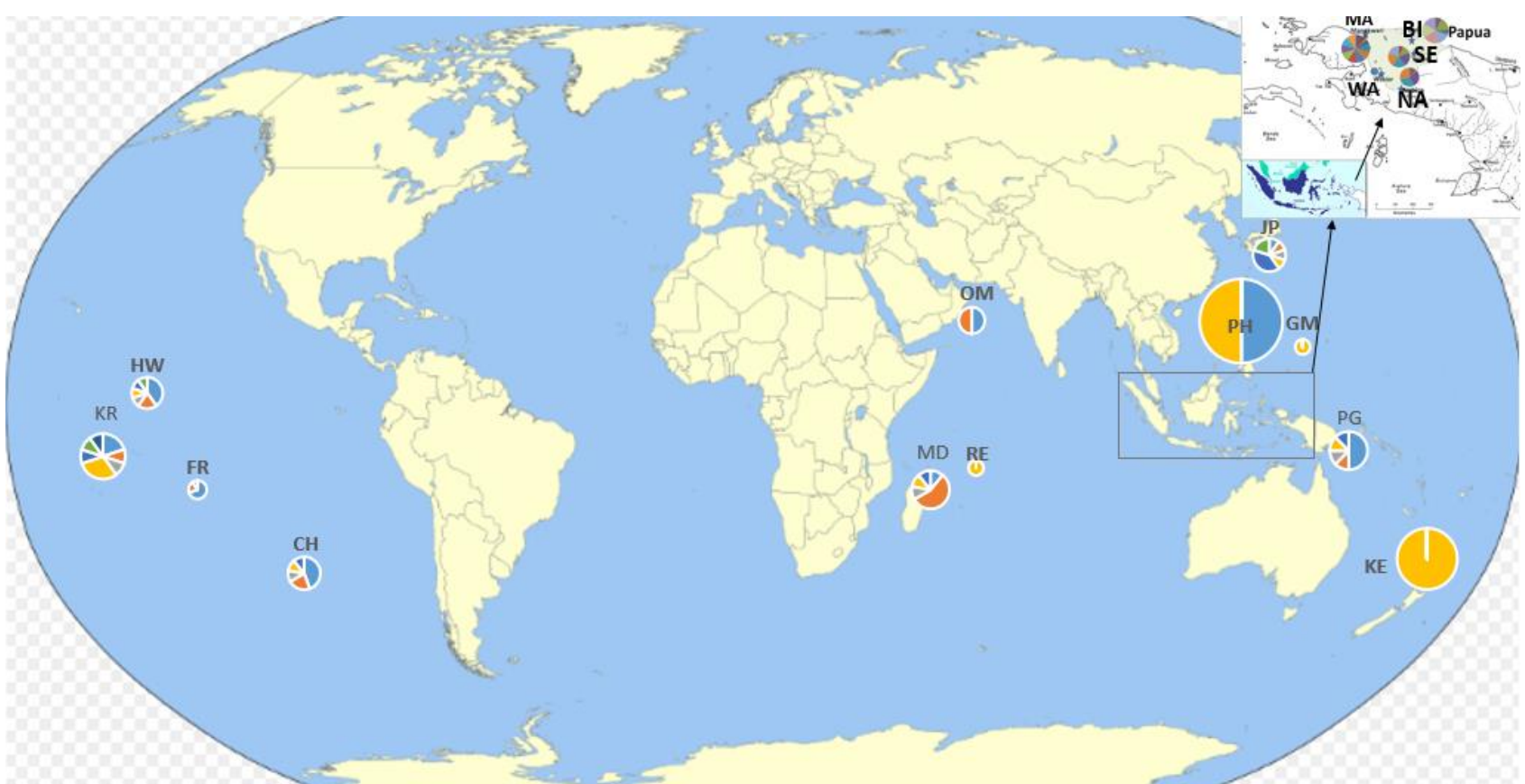

NA Nabire, WA Wasior, MA Manokwari, BI Biak, SE Yapen, OM Oman, RE Reunion, MD Madagascar, CH Chili_Easter_Islands, FR French_Polynesia, GM Guam, HW Hawaii, JP Japan, KE Kermadec, KR Kiritimati, PG Papua New Guinea, PH Philippines.

Figure 1. Map of study locations and their haplotypes frequency. Sampling location of T. gratilla from inside of Cenderawasih Bay (Wasior, Yapen and Nabire) and outside of the bay (Manokwari and Biak)(insert). Pie indicated the size of the haplotypes frequency at each location. Every color in the pie indicated the number and kind of haplotype. Dash line insert is a barrier hypothesis that isolates between inside and outside of the Cenderawasih Bay 


\subsection{Sequence Analyses}

The numbers of variable sites were assessed with MEGA6 (Tamura et al. 2013). Polymorphic site and haplotype were calculated using the DnaSP software version 5 (Librado and Rozas 2009). We also created a haplotype network using the program Network 4.6.0.0 to examine the distribution of haplotypes among populations (Bandelt 1994). Genetic structure of the population was tested by Analyzing Molecular Variance (AMOVA), used Arlequin version 3.5 (Excoffier and Lischer 2010). The test was done at three hierarchical, i.e. among groups (inside and out the region of the Cenderawasih Bay), among populations within groups, and within populations levels. The samples were grouped into two, i.e. inside (Nabire, Wasior, and Yapen population) and out region (Manokwari and Biak populations) of the bay. Phylogenetic reconstruction of $T$. gratilla was done with neighbor-joining method using MEGA6. Bootstrap resampling $(n=1,000)$ was performed to test the robustness of the dendrogram topologies using MEGA6 (Tamura et al. 2013).

\section{Results}

The COI mtDNA sequences of the $T$. gratilla obtained in this study have been deposited at GenBank under accession No. KX598982 to KX599057. A total of 592 bp of CO1 mtDNA were sequenced from 76 samples of five populations.
The 28 polymorphic sites, including 19 singletons and nine parsimoniously informative sites were found from the sequences. In total polymorphism were 43 transitions $(10.17+5.43)$, one transversions $(0.17+0.37)$ and 44 substitutions $(10.33+5.50)$. Despite all samples having 25 haplotypes but only five haplotypes were shared among all populations (Table 1, Figure 1). The haplotype network reveals that most common haplotype (No. 5) found in 14 individuals that occurred in all populations. Haplotype 1 was found in 29 individuals, which is the share in four populations. Besides haplotype 2 and 4 are found in five and four samples, respectively, in three populations in Papua.

Haplotype diversity (Hd) was moderate to high in all populations (0.84 in Biak, 0.75 in Manokwari, 0.80 in Nabire, 0.87 in Yapen, and 0.67 in Wasior). Therefore the nucleotide diversity $(\pi)$ was low for all samples (0.003), with values from 0.002 (Wasior and Manokwari) to 0.003 (Nabire, Biak and Yapen). According to Tajima's D, Fu and Li's D statistical tests indicated that hypotheses of selective neutrality among the population were rejected (Tajima's D $=2.233, \mathrm{P}<0.01 ; \mathrm{Fu}$ and Li's $\mathrm{D}=-4.278, \mathrm{P}<0.02$ ). Furthermore, we use AMOVA to determine the variation of the species' populations. Result of the analysis showed that the source of variation (SV) of the total sequence divergences in $T$. gratilla was not differ significantly (Table 2). Genetic variation within the population nearly 95\% (high), but the

Table 1. Summary of included data and genetic diversity statistics for five studied location and 12 other locations from GenBank AY205373- 455 (Lessios et al. 2003), JX661089-167 (Casilagan 2012), KF012802-824 (Liggins et al. 2014) as a comparison: number of sequences $(n)$, polymorphic sites $(\theta)$, number of haplotypes $(H)$, haplotype diversity [Hd (SD)], nucleotide diversity [ $\pi(\mathrm{SD})]$, Tajima's D statistic and significance (P, no correction). Source (Src) of the C01 data: ${ }^{*}=$ present study, a = Lessios et al. (2003), b = Casilagan (2012), c = Liggins et al. (2014)

\begin{tabular}{|c|c|c|c|c|c|c|c|c|c|}
\hline Location & Code & $\mathrm{n}$ & $\theta$ & $\mathrm{H}$ & Hd & $\pi$ & Tajima's D & $\mathrm{P}$ & $\mathrm{Scr}$ \\
\hline Biak & $\mathrm{BI}$ & 17 & 1 & 9 & 0.84 & 0.003 & 2.05808 & 0.00600 & \\
\hline Manokwari & MA & 34 & 12 & 11 & 0.75 & 0.002 & -1.77741 & 0.01600 & \\
\hline Nabire & NA & 11 & 8 & 6 & 0.80 & 0.003 & -1.05273 & 0.17000 & \\
\hline Yapen (Serui) & SE & 11 & 4 & 5 & 0.87 & 0.003 & -0.44419 & 0.35500 & \\
\hline Wasior & WA & 3 & 2 & 2 & 0.67 & 0.002 & 0.00000 & 0.93100 & \\
\hline Chile_Easter Island & $\mathrm{CH}$ & 8 & 5 & 5 & 0.8 & 0.003 & -0.83938 & 0.23700 & \\
\hline French_Polynesia & FR & 9 & 8 & 3 & 0.5 & 0.004 & -1.36919 & 0.09600 & \\
\hline Guam & GM & 2 & 0 & 1 & 0 & 0 & 0.00000 & 1.00000 & \\
\hline Japan & JP & 10 & 6 & 6 & 0.8 & 0.004 & -0.49593 & 0.34500 & \\
\hline Kiribati_Kiritimati & $\mathrm{KR}$ & 10 & 7 & 7 & 0.9 & 0.004 & -0.24147 & 0.41700 & \\
\hline Madagascar & MD & 8 & 7 & 5 & 0.7 & 0.004 & -1.35929 & 0.09400 & \\
\hline Oman & OM & 2 & 1 & 2 & 1 & 0.002 & 0.00000 & 1.00000 & \\
\hline Papua New Guinea & PG & 7 & 7 & 5 & 0.8 & 0.003 & -1.52412 & 0.03100 & \\
\hline Philippines & $\mathrm{PH}$ & 91 & 62 & 69 & 0.9 & 0.006 & -2.45365 & 0.00000 & $a, b$ \\
\hline Reunion & $\mathrm{RE}$ & 5 & 0 & 1 & 0 & 0 & 0.00000 & 1.00000 & \\
\hline USA_Hawaii & HW & 10 & 7 & 6 & 0.8 & 0.003 & -1.38265 & 0.07900 & \\
\hline Kermadec Islands & $\mathrm{KE}$ & 23 & 62 & 22 & 0.9 & 0.006 & -1.92094 & 0.01300 & \\
\hline
\end{tabular}


variation among populations in the Cenderawasih bay was low (2.80\%). Besides the variation between inside and outside populations of the bay was low (2.35\%). Fixation indices of F-statistics (Fct, Fsc, Fst) values were close to zero, which is indicated the genetic among populations was not different.

The Tajima D statistic was also significantly negative at most sites for all populations in Cenderawasih Bay and Indo-Pacific regions, indicating departures from neutral expectations for the number of recent mutations. T. gratilla in all locations were not significant, most likely due to the admixture of a few divergent clades. These results are expected in the case of past population expansion. These results suggested that the $T$. gratilla from the inside and outside of Cenderawasih Bay and IndoPacific were connected to each other (Figure 2).

The data is consistent with the results from neighbor-joining tree analysis of the COI sequences of T.gratilla (Figure 3). The phylogeny clearly revealed that all samples were considered a single clade due to low bootstrap support for identified clades. The phylogeny and median-joining haplotype networks also show that individuals among locations have strong connectivity with each other.

Using AMOVA to partition genetic variation into Indo-Pacific (including Cenderawasih Bay), we found evidence of low genetic structure in all $T$. gratilla (Table 3).

There is strong genetic connectivity among the population of $T$. gratilla in Cenderawasih Bay and between $T$. gratilla in Cenderawasih and Indo-Pacific regions. Assuming no a priori structure in T. gratilla, Fst $=0.051(P>0.006)$. There was not significant structure between Indian Ocean (Oman, Reunion, and Madagascar), Pacific Ocean (Chili Easter, French Polynesia, Gua, Hawaii, Japa, Kermadec, Kiritimati, PNG, and Philippines), and Cenderawasih Bay (Wasior, Nabire, Yapen, included Manokwari and Biak) regions in the study area $(\mathrm{Fct}=-0.001, \mathrm{P}>0.385)$.

Table 2. AMOVA based on COI mtDNA gene of $T$. gratilla in Cenderawasih Bay

\begin{tabular}{|c|c|c|c|c|c|}
\hline Source of variation & df & Sum of squares & $\begin{array}{c}\text { Variance } \\
\text { components }\end{array}$ & $\begin{array}{l}\text { Fixation } \\
\text { indices }\end{array}$ & P value \\
\hline Among groups & 2 & 1.46 & 0.010 & $\mathrm{~F}_{\mathrm{CT}}=0.023$ & 0.371 \\
\hline Among populations within groups & 2 & 1.11 & 0.012 & $F_{S C}=0.029$ & 0.163 \\
\hline Within populations & 70 & 27.71 & 0.396 & $\mathrm{~F}_{\mathrm{ST}}^{\mathrm{sc}}=0.052$ & 0.052 \\
\hline Total & 74 & 30.28 & 100.00 & & \\
\hline
\end{tabular}

AMOVA calculation by 1023 permutations. Degree of freedom (d.f), probability (P), Fixation indices of samples from group level (FCT), Fixation indices of samples from populations (FSC), Fixation indices of samples within populations level (FST). Groups are divided into two regions namely region in bay (consist of Nabire, Wasior, and Yapen population) and out the bay (consist of Manokwari and Biak populations)

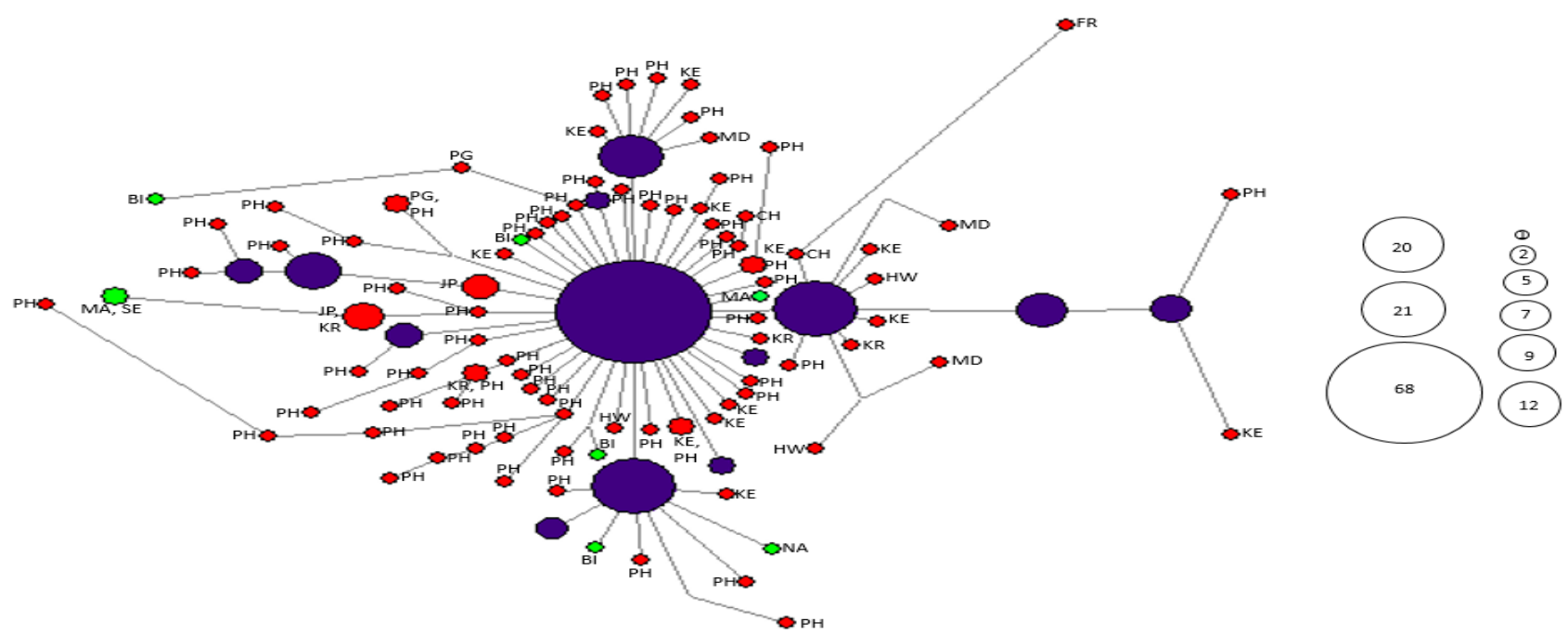

Figure 2. Median-joining haplotype networks for T. gratilla displaying which haplotype is found in the Cenderawasih Bay, Papua (green tone), which haplotypes are shared among locations in Indo-Pacific region and found in the Papua (purple tone), and haplotypes that are not found in the Papua (red tone, also with location code indicated). The frequency of each haplotype is indicated by size (see key, right). NA Nabire, WA Wasior, MA Manokwari, BI Biak, SE Yapen, OM Oman, RE Reunion, MD Madagascar, CH Chili_Easter_Islands, FR French_Polynesia, GM Guam, HW Hawaii, JP Japan, KE Kermadec, KR Kiritimati, PG Papua New Guinea, PH Philippines 


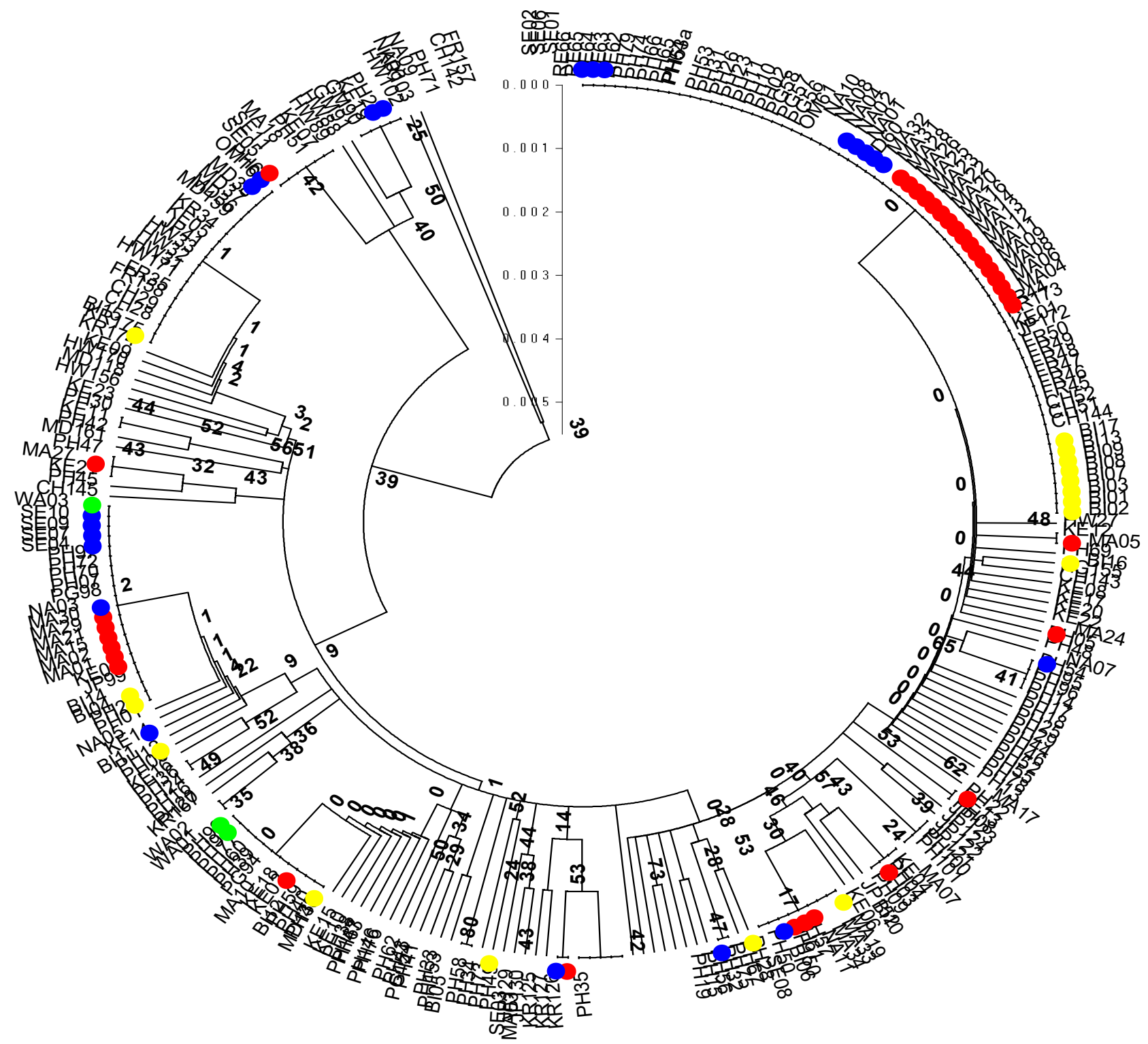

Figure 3. Neighbor-joining tree of the COI sequences of T. gratilla from Cenderawasih Bay and GenBank, based on Kimura 2-parameter distance. Color circles represent locations of sequence from Cenderawasih Bay ecoregion i.e. yellow (Biak), red (Manokwari), blue (Nabire), black (Yapen or Serui) and green (Wasior). The numbers at the nodes are bootstrap percent probability values based on 1,000 replications. NA Nabire, WA Wasior, MA Manokwari, BI Biak, SE Yapen, OM Oman, RE Reunion, MD Madagascar, CH Chili_Easter_Islands, FR French_Polynesia, GM Guam, HW Hawaii, JP Japan, KE Kermadec, KR Kiritimati, PG Papua New Guinea, PH Philippines

Table 3. AMOVA based on COI mtDNA gene of T. gratilla in Cenderawasih Bay and Indo-Pacific

\begin{tabular}{lrccccr}
\hline Source of variation & df & Sum of squares & $\begin{array}{c}\text { Variance } \\
\text { components }\end{array}$ & $\begin{array}{c}\text { Percentage } \\
\text { of variation }\end{array}$ & $\begin{array}{c}\text { Fixation } \\
\text { indices }\end{array}$ & P value \\
\hline Among groups & 2 & 1.46 & 0.010 & 3.20 & $\mathrm{~F}_{\mathrm{CT}}=0.023$ & 0.371 \\
Among populations within groups & 2 & 1.11 & 0.012 & 5.33 & $\mathrm{~F}_{\mathrm{SC}}=0.029$ & 0.163 \\
Within populations & 70 & 27.71 & 0.396 & 91.47 & $\mathrm{~F}_{\mathrm{ST}}=0.052$ & 0.052 \\
\hline Total & 261 & 119.62 & 0.469 & 100.00 & &
\end{tabular}

AMOVA calculation by 1023 permutations. Degree of freedom (d.f), probability.(P), Fixation indices of samples from group level (FCT), Fixation indices of samples from populations (FSC), Fixation indices of samples within populations level (FST). Groups are divided into three regions namely region in bay (consist of Nabire, Wasior, Manokwari, Biak, and Yapen locations), Hindia (Oman, Reunion, and Madagascar) and Pacific (consist of Chili_Easter_Islands, French_ Polynesia, Guam, Hawaii, Japan, Kermadec, Kiritimati, PNG, Philippines) 


\section{Discussion}

The number of haplotypes of $T$. gratilla in each population at Cenderawasih Bay was moderate to high. This results similar to other invertebrates, i.e. Tridacna maxima (Nuryanto and Kochzius 2009), T. crocea and T. maxima (DeBoer et al. 2014), Haptosquilla pulchella (Barber et al. 2002). Liggin et al. (2014) determined 23 haplotypes of COI gene of $T$. gratilla from Kermadec Island (Southwest Pacific), now this species under the name Tripneustes kermadecensis (Bronstein et al. 2017). The analyzing of 82 COI gene fragment sequences of $T$. gratilla from 11 locations in Indo-Pacific accessed from the GenBank data (Lessios et al. 2003) resulted in 34 haplotypes. These results are similar with allelic richness using microsatellite markers in previous studies of $T$. gratilla in South African coast (Brink et al. 2018), in the Philippines (Casilagan et al. 2013), the Philippines and the Indonesian Archipelago (Wainwright et al. 2013), and in Hawaii (Carlon and Lippé 2007).

Despite all populations having high haplotype diversity, the nucleotide diversity was low. This combination was similar to $T$. gratilla population in the Indo-Pacific (Lessios et al. 2003; Liggins et al. 2014), and many others marine taxa (Rocha et al. 2002 on Bowen et al. 2001), such as H. pulchella (Barber et al. 2002) and T. crocea (Kochzius and Nuryanto 2008; DeBoer et al. 2014). The high levels of haplotype diversity and low levels of nucleotide diversity indicated either a long stable evolutionary history or secondary contact among differentiated lineages (Väli et al. 2019). According to Plough (2016), this combination has frequently been attributed to expansion after a period of small effective population size, retaining new mutations and related to episodes of marine level oscillations (e.g. Barber et al. 2002).

The haplotypes were spread evenly inside and out the region of Cenderawasih Bay, suggesting that gene flow between those areas have occurred. This condition is supported by AMOVA tests that are unable to differentiate genetic variation between populations from inside and outside of the bay and also between Cenderawasih Bay and Indo-Pacific. Population within the Indo-Pacific appears to be panmictic as there are no statistically significant differences. Mitochondrial sequence variation showed very weak regional divergence of Tripneustes populations across the Indo-Pacific region despite the significant local differentiation among the populations in this region (Casilagan et al. 2013).

According to Mora et al. (2011), marine species often have high dispersal potential influencing their genetic diversity as well as connectivity can be maintained in peripheral populations by immigration. Then, the influence of immigration and local reproductive success, often determined by ecological circumstances, can promote patterns of genetic diversity and differentiation that do not conform to the expectations for a peripheral population according to the CorePeriphery Hypothesis (Liggins et al. 2014). The CPH also known as the "central-marginal hypothesis," predicts that these genetic patterns at the edge-ofrange are a consequence of reduced population size and connectivity toward a species range periphery. López-Márquez et al. (2019) stated connectivity among populations, and patterns of dispersal and gene flow, are primarily determined by the physical characteristics of the landscape occupied by a species and the biological life-history traits of that species.

The result was parallel with phylogeny analysis and haplotype network that all samples for T. gratilla were considered a single clade and connected each other. Therefore, the result suggested that all populations of $T$. gratilla in Cenderawasih Bay had the same evolutionary history and connected with each other including with Indo-Pacific. The phenomenon occurs through dispersal of $T$. gratilla during larvae period. The species has a larval stage for 20 to 52 days under culture conditions (Shimabukuro 1991; Lawrence and Agatsuma 2013) and thus have potential to disperse relatively large distances. Taken together, overall genetic analysis suggested that the entire population of $T$. gratilla were closed connected, homogeneous, and shared polymorphic profile (Lessios et al. 2003; Liggins et al. 2014). The condition is indicating that gene flow occurred high and for a long time among the populations. This implies that $T$. gratilla in this region belongs to a large Tripneustes metapopulation (Lessios et al. 2003).

Since T. gratilla has no endemicity in Cenderawasih Bay, and then we assumed that the geography of the bay is not able to isolate the species spread to other places. These conditions were similar to whale shark Rhincodon typus population in the Indo-Pacific including in the Cenderawasih bay ecoregion (Toha et al. 2016; Toha et al. 2020). The hypothesis is supported by the previous report on $T$. gratilla from along the South African coast (Brink et al. 2018) and the Philippines (Casilagan et al. 2013) and other species of sea urchin, such as Eucidaris (Lessios et al. 1999), Diadema paucispinum and D. setosum (Lessios et al. 2001 ) in Indo-Pacific.

These results were contrary to other report that explained mantis shrimp (Barber et al. 2002, 2006), starfish (Crandall et al. 2008), Astreopora (Scleractinia: Acroporidae) (Wallace et al. 2011), Linckia laevigata (Crandall et al. 2008), T. maxima (Nuryanto and 
Kochzius 2009), T. crocea and T. maxima (DeBoer et al. 2014), Gonodactylinus viridis (Barber et al. 2006), and Protoreaster nodosus (Crandall et al. 2008) were isolated in Cenderawasih Bay (see Allen and Erdmann 2008; Allen and Erdmann 2009; Alonso et al. 2011). In these cases, connectivity may be restricted due to the relatively sheltered nature of the bay, limiting water and larval movement to outside populations. Wainwright et al. (2019) proposed that the observed genetic differentiation of $T$. gratilla is the result of habitat loss during periods of glacial maxima and differences in physical oceanographic properties throughout Indonesia.

\subsection{Consequences for Conservation}

According to Bertocci et al. (2018), the high demand for Uni has led to overexploitation and depletion of many urchin populations in their natural habitat. Consequently, the world sea urchin fishery is now in a state of decline (Stefánsson et al. 2017; FAO 2020). Characterising genetic diversity and structure of populations is essential for effective conservation of threatened species (Väli et al. 2019). According to Goodall-Copestake et al. (2012) estimates of genetic diversity represent a valuable resource for biodiversity assessments and could be used to guide conservation and management programs. Wainwright et al. (2019) stated the documentation of cryptic diversity will aid in the identification of hot spots of biodiversity and ultimately its conservation.

The maintenance of genetic diversity within species is critically important as insurance for the ability of populations to survive and reproduce through global climate change. This diversity gives populations and species a better chance that at least some individuals bear the traits necessary to ensure environmental changes. Genetic diversity represents the very building blocks of adaptation and natural selection, and serves as a primary buffer against extirpations and even extinction. To minimize marine extinctions, Indonesia's national marine conservation and MPA strategy and Papua was overwhelmingly ranked the top marine biodiversity conservation priority in Indonesia and must include a focus on maintaining genetic diversity (Huffard et al. 2012).

Results from this study clearly indicated that T. gratilla populations from Cenderawasih Bay in Papua-Indonesia have strong genetic connectivity. The results also show strong connectivity among $T$. gratilla populations from Cenderawasih Bay and IndoPacific, indicating a general pattern of panmixia among these regions. According to Brink et al. (2018), the panmixia observed within these natural populations of $T$. gratilla indicated that they could be managed as a single genetic stock. The establishment of a large transboundary marine protected area has existed for the region namely Cenderawasih Bay National Park covers 1,453,500 hectares (Mangubhai et al. 2012).

Existing infrastructure and capacity in Cenderawasih Bay National Park should serve as a sound expansion point for conservation, which should include the creation of a network of MPAs running north to south and creating a "connectivity corridor" along the Cenderawasih Ecoregion. Integral role in connectivity and larval dispersal suggested an effective strategy to maintain biodiversity in the Cenderawasih Bay is to connect of the two actively managed of Marine Protected Area (MPAs) viz., Taman Nasional Teluk Cenderawasih covers 1,453,500 hectares; and Padaido Islands Marine Tourism Park covers 183,000 hectares (Mangubhai et al. 2012) and others. The network of seven MPAs in the Raja Ampat region (PapuaIndonesia) is an excellent example of this approach (Starger et al. 2015).

In conclusion, haplotype diversity of $T$. gratilla was moderate to high and spread evenly across the Cenderawasih bay. The entire populations of $T$. gratilla in Cenderawasih Bay were closed connected and shared polymorphic profile. The phenomenon is indicating that gene flow occurred high and for a long time among populations including Indo-Pacific regions.

\section{Disclosure Statement}

The authors report no conflicts of interest. The authors alone are responsible for the content and writing of the paper.

\section{Acknowledgements}

We thank R. Binur, Suhaemi, Hemawaty Abubakar, Lutfi and S.A. La Aji for their support to collect samples and data. This work was supported by National Strategic Research by DGHE of Indonesia to AHAT, and the Marine Biodiversity of Raja Ampat Islands project who funded by USAID_NAS_Grant_PGA-2000001991 and World Class Research University of Diponegoro University.

\section{References}

Allen, G.R., Erdmann, M.V., 2008. Pterocaesio monikae, a new species of fusilier (Caesionidae) from western New Guinea (Papua and Papua Barat provinces, Indonesia). Aqua. International Journal of Ichthyology. 13, 163-170.

Allen, G.R., Erdmann, M.V., 2009. Two new species of damselfishes (Pomacentridae: Chromis) from Indonesia. Aqua, International Journal of Ichthyology. 15, 121-134. https://doi.org/10.18195/issn.0312-3162.25(2).2009.121126 
Alonso, L.E., Deichmann, J.L., McKenna, S.A., Naskrecki, P., Richards, S.J., 2011. Still Counting...: Biodiversity Exploration for Conservation-The First 20 Years of the Rapid Assessment Program. Conservation International, Arlington.

Bandelt, H.J., 1994. Phylogenetic networks. Verhandl Naturwiss Vereins Hamburg. 34, 51-71.

Barber, P.H., Palumbi, S.R., Erdmann, M.V., Moosa, M.K., 2002. Sharp genetic breaks among populations of a benthic marine crustacean indicate limited oceanic larval transport: patterns, causes, and consequences. Molecular Ecology. 11, 659-674. https:// doi.org/10.1046/j.1365-294X.2002.01468.X

Barber, P.H., Erdmann, M.V., Palumbi, S.R., 2006. Comparative phylogeography of three codistributed stomatopods: origins and timing of regional lineage diversification in the coral Triangle. Evolution. 60, 1825-1839. https:// doi.org/10.1111/j.0014-3820.2006.tb00526.x

Bertocci, I., Blanco, A., Franco, J.N., Fernández,-Boo, S., Arenas, F., 2018. Short-term variation of abundance of the purple sea urchin, Paracentrotus lividus (Lamarck, 1816), subject to harvesting in northern Portugal. Marine Environmental Research. 141, 247-254. https:// doi.org/10.1016/j.marenvres.2018.09.017

Bowen, B.W., Bass, A.L., Rocha, W.S., Grant, W.S., Robertson, D.R., 2001. Phylogeography of the trumpetfishes (Aulostomus): ring species complex on a global scale. Evolution. 55, 1029-1039. https://doi. org/10.1554/0014-3820(2001)055[1029:POTTAR]2. $0 . \mathrm{CO} ; 2$

Brink, M., Kuys, R.D., Rhode, C., Macey, B.M., Christison, K.W., Roodt-Wilding, R., 2018. Genetic diversity and population connectivity of the sea urchin Tripneustes gratilla along the South African coast. African Journal of Marine Science. 40, 149-156. doi:10.2989/181423 2X.2018.1468819

Brink, M., Rhode, C., Macey, B.M., Christison, K.W., RoodtWilding, R., 2019. Metagenomic assessment of body surface bacterial communities of the sea urchin, Tripneustes gratilla. Marine Genomics. 47, 100675. https://doi.org/10.1016/j.margen.2019.03.010

Bronstein, O., Kroh, A., Tautscher, B., Liggins, L., Haring, E., 2017, Cryptic speciation in pan-tropical sea urchins: a case study of an edge-of-range population of Tripneustes from the Kermadec Islands. Scientific Reports. 7, 1-16. DOI:10.1038/s41598-017-06183-2

Carlon, D.B., Lippé, C., 2007. Eleven new microsatellite markers for the tropical sea urchin Tripneustes gratilla and cross-amplification in Tripneustes ventricosa. Molecular Ecology Resources. 7, 1002-1004. https:// doi.org/10.1111/j.1471-8286.2007.01755.x

Carpenter, K.E., Barber, P.H., Crandall, E.D., Ablan-Lagman, Ma.,CA., Ambariyanto, Mahardika, G.N., ManjajiMatsumoto, B.M., Juinio-Me nez, M.A., Santos, M.D., Starger, C.J., Toha, A.H.A., 2011. Comparative phylogeography of the coral triangle and implications for marine management. Journal of Marine Biology. 2011, 14. https://doi.org/10.1155/2011/396982

Casilagan, I.L.N., 2012. Spatial and temporal aspects of genetic variation in sea urchin, Tripneustes gratilla populations in western Luzon, Philippines. Unpublished.

Casilagan, I.L.N., Juinio-Meñez, M.A., Crandall, E.D. 2013. Genetic diversity, population structure, and demographic history of exploited sea urchin populations (Tripneustes gratilla) in the Philippines. Journal of Experimental Marine Biology and Ecology. 449, 284-293. https://doi.org/10.1016/j.jembe.2013.09.012

Crandall, E.D., Jones, M.E., Mũ̃noz, M.M., Akinronbi, B., Erdmann, M.V., Barber, P.H., 2008. Comparative phylogeography of two seastars and their ectosymbionts within the Coral Triangle. Molecular Ecology. 17, 5276-5290. https://doi.org/10.1111/ j.1365-294X.2008.03995.X
DeBoer, T.S., Naguit, M.R.A., Erdmann, M.V., AblanLagman, M.C.A., Ambariyanto, Carpenter, K.E., Toha, A.H.A., Barber, P.H., 2014. Concordance between phylogeographic and biogeographic boundaries in the Coral Triangle: conservation implications based on comparative analyses of multiple giant clam species. Bulletin of Marine Science. 90, 277-300. http://dx.doi. org/10.5343/bms.2013.1003

Excoffier, L., Lischer, H.E.L., 2010. Arlequin suite ver 3.5: a new series of programs to perform population genetics analyses under Linux and Windows. Molecular Ecology Resources. 10, 564-567. https://doi.org/10.1111/j.17550998.2010.02847.x

[FAO] Food and Agriculture Organization. 2020. The State of World Fisheries and Aquaculture 2020. Sustainability in action. Rome. https://doi.org/10.4060/ca9229en

Goodall-Copestake, W.P., Tarling, G.A., Murphy, E.J., 2012, On the comparison of population-level estimates of haplotype and nucleotide diversity: a case study using the gene cox1 in animals. Heredity. 109, 50-56. https://doi.org/10.1038/hdy.2012.12

Huffard, C.L., Erdmann, M.V., Gunawan, T.R.P., 2012. Geographic Priorities for Marine Biodiversity Conservation in Indonesia. Ministry of Marine Affairs and Fisheries and Marine Protected Areas Governance Program, Jakarta.

Jacobs, H.T., David, J.E., Veerabhadracharya, B.M., Andrew F., 1988. Nucleotide sequence and gene regulation of sea urchin mitochondria DNA. Journal of Molecular Biology. 202, 185 - 217. https://doi.org/10.1016/00222836(88)90452-4

Kochzius, M., Nuryanto, A., 2008. Strong genetic population structure in the boring giant clam, Tridacna crocea, across the Indo-Malay Archipelago: implications related to evolutionary processes and connectivity. Molecular Ecology 17, 3775-3787. https://doi. org/10.1111/j.1365-294X.2008.03803.x

Kroh, A., Mooi, R., 2019. WoRMS Echinoidea: World Echinoidea Database (version 2019-03-05). In: Roskov Y., Ower, G., Orrell, T., Nicolson, D., Bailly, N., Kirk, P.M., Bourgoin, T., DeWalt, R.E., Decock, W., Nieukerken, E., van, Zarucchi, J., Penev, L., (Eds.), Species 2000 and ITIS Catalogue of Life, 2019. Annual Checklist Digital resource at www.catalogueoflife.org/annualchecklist/2019, Naturalis, Leiden, the Netherlands.

Kroh, A., Mooi, R., 2020. World Echinoidea Database. Tripneustes gratilla (Linnaeus, 1758). Available at: http://www. marinespecies.org/aphia.php? $\mathrm{p}=$ taxdetails\&id $=212453$. [Date accessed: 13 November 2021 ]

Lawrence, J.M., Agatsuma, Y., 2013. Tripneustes. In: Lawrence, J.M., (Eds.), Sea urchins: Biology and ecology. Oxford: Elsevier. pp. 491-507. https://doi.org/10.1016/B9780-12-396491-5.00032-0

Lessios, H.A., Kane, J., Robertson, D.R., 2003. Phylogeography of the pantropical Sea Urchin Tripneustes: Constrasting patterns of population structure between oceans. Evolution. 57, 2026-2036. https:// doi.org/10.1111/j.0014-3820.2003.tb00382.x

Lessios, H.A., Kessing, B.D., Robertson, D.R., Paulay, G. 1999. Phylogeography of the pantropical sea urchin Eucidaris in relation to land barriers and ocean currents. Evolution. 53, 806-817. https://doi. org/10.1111/j.1558-5646.1999.tb05374.x

Lessios, H.A., Kessing, B.D., Pearse, J.S., 2001. Population structure and speciation in tropical seas: phylogeography of the sea urchin Diadema. Evolution. 55, 955-975. https://doi.org/10.1554/00143820(2001)055[0955:PSASIT]2.0.CO;2

Librado, P., Rozas, J., 2009. DnaSP v5: a software for comprehensive analysis of DNA polymorphism data. Bioinformatics. 25, 1451-1452. https://doi. org/10.1093/bioinformatics/btp187 
Liggins, L., Gleeson, L., Riginos, C., 2014. Evaluating edgeof-range genetic patterns for tropical echinoderms, Acanthaster planci and Tripneustes gratilla, of the Kermadec Islands, southwest Pacific. Bulletin of Marine Science. 90, 379-397. http://dx.doi.org/10.5343/ bms.2013.1015.

López-Márquez, V., Templado. J., Buckley, D., Marino, I., Boscari, E., Micu, D., Zane, L., Machordom, A., 2019. Connectivity Among Populations of the Top Shell Gibbula divaricata in the Adriatic Sea. Front. Genet. 10, 177. https://doi.org/10.3389/fgene.2019.00177

Mangubhai, S., Erdmann, M.V., Wilson, J.R., Huffard, C.L. Ballamu, F., Hidayat, N.I., Hitipeuw, C., Lazuardi, M.E., Muhajir, Pada, D., Purba, G., Rotinsulu, C., Rumetna, L., Sumolang, K., Wena, W., 2012. Papuan bird's head seascape: emerging threats and challenges in the global center of marine biodiversity. Marine Pollution Bulletin. 64, 2279-2295. https://doi.org/10.1016/j. marpolbul.2012.07.024

Mora, C., Treml, E.A., Roberts, J., Crosby, K., Roy, D., Tittensor D.P., 2011. High connectivity among habitats precludes the relationship between dispersal and range size in tropical reef fishes. Ecography. 35, 89-96. http:// dx.doi.org/10.1111/j.1600-0587.2011.06874.

Nane, L., Paramata, A.R., 2020. Impact of overfishing on density and test-diameter size of the sea urchin Tripneustes gratilla at Wakatobi Archipelago, SouthEastern Sulawesi, Indonesia. Ilmu Kelautan: Indonesia journal of marine science. 25, 53-56. https://doi. org/10.14710/ik.ijms.25.2.53-56

Nuryanto,A., Kochzius, M., 2009. Highly restricted gene flow and deep evolutionary lineages in the giant clam Tridacna maxima. Coral. Reefs. 28, 607-619. https:// doi.org/10.1007/s00338-009-0483-y

Onomu, A.J., Vine, N.G., Cyrus, M.D., Macey, B.M., Bolton, J.J., 2020. The effect of fresh seaweed and a formulated diet supplemented with seaweed on the growth and gonad quality of the collector sea urchin, Tripneustes gratilla, under farm condition. Aquaculture Research. 51, 4087-4102. https://doi.org/10.1111/are.14752

Parvez, M.S., Rahman, M.A., Yusoff, F.M., Arshad, A., Lee, S.G., 2018. Influence of temperature variation on embryonic and early larval development of a commercially important tropical sea urchin Tripneustes gratilla (Linnaeus, 1758). Indian Journal of Fish. 65, 72-81. https://doi.org/10.21077/ijf.2018.65.2.72728-09

Plough, L.V., 2016. Genetic load in marine animals: a review. Current Zoology. 62, 567-579. https://doi.org/10.1093/ CZ/zow096

Rocha, L.A., Bass, A.L., Robertson, D.R., Bowen, B.W., 2002. Adult habitat preferences, larval dispersal, and the comparative phylogeography of three Atlantic surgeonfishes (Teleostei: Acanthuridae). Mol. Ecol. 11, 243-252. https://doi.org/10.1046/j.09621083.2001.01431.X

Shimabukuro, S., 1991. Tripneustes gratilla (sea urchin), in: Shokita, S.K., Kakasu, K., Tomori, A., Toma, T., (Eds.), Aquaculture in Tropical Areas. Midori Shobo Co. Ltd., Japan, pp. 313-318.

Starger, C.J., Erdmann, M.V., Toha, A.H.A., Baker, A.C., Barber, P.H. 2015. Strong genetic structure among coral populations within a conservation priority region, the Bird's Head Seascape (Papua, Indonesia).Frontiers of Biogeography. 7, 91-106. https://doi.org/10.21425/ F5FBG22326

Stefánsson, G., Kristinsson, H., Ziemer, N., Hannon, C., James, P., 2017. Markets for sea urchins: a review of global supply and markets. Matís. 45, 10-17.
Tamura, K., Stecher, G., Peterson, D., Filipski, A., Kumar, S., 2013. MEGA6: molecular evolutionary genetics analysis version 6.0. Mol. Biol. Evol. 30, 2725-2729. https://doi.org/10.1093/molbev/mst197

Toha, A.H.A., Binur, R., Suhaemi, Lutfi, Hakin, L., Widodo, N., Sumitro, S.B., 2014. Genetic aspects of the commercially used sea urchin Tripneustes gratilla. Journal of Biological Researches. 20, 12-17. https:// doi.org/10.23869/bphjbr.20.1.20143

Toha, A.H.A., Dailami, M., Anwar, S., Setiawan, J.B.S., Jentewo, Y., Lapadi, I., Sutanto, S., Aryasari, R., Ambariyanto, Runtuboi, F., Madduppa, H., 2020. The genetic relationships and Indo-Pacific connectivity of whale sharks (Rhincodon typus) with particular reference to mitochondrial COI gene sequences from Cenderawasih Bay, Papua, Indonesia. Biodiversitas. 21, 2159-2171. https://doi.org/10.13057/biodiv/d210544

Toha, A.H.A., Sumitro, S.B., Hakim, L., Widodo, 2012. Kondisi Habitat bulu babi Tripneustes gratilla (Linnaeus, 1758) di Teluk Cenderawasih. Berk. Penel. Hayati. 17, 139145. https://doi.org/10.23869/bphjbr.17.2.20123

Toha, A.H.A., Sumitro, S.B., Hakim, L., Widodo, N., 2017. Biology of the commercially used sea urchin Tripneustes gratilla (Linnaeus, 1758)(Echinoidea: Echinodermata). Ocean Life. 1, 1-10. https://doi.org/10.13057/oceanlife/ o010101

Toha, A.H.A., Sumitro, S.B., Widodo, Hakim, L., 2015. Color diversity and distribution of Sea Urchin Tripneustes gratilla in Cenderawasih Bay ecoregion of Papua, Indonesia. The Egyptian journal of aquatic research. 41, 273-278. https://doi.org/10.1016/j.ejar.2015.05.001

Toha, A.H.A., Widodo, N., Subhan, B., Himawan, M.H., Tania, C., Noor, B.A., Stewart, B.S., Madduppa, H.H., 2016. Close genetic relatedness of whale sharks, Rhincodon typus in the Indo-Pacific region. AACL Bioflux. 9, 458465.

Veron, J., DeVantier, L.M., Turak, E., Green, A.L., Kininmonth, S., Stafford-Smith, M., Peterson, N., 2009. Delineating the Coral Triangle. Galaxea. 11, 91-100.

Väli, Ü., Dombrovski, V., Dzmitranok, M., Maciorowski, G. Meyburg, B.U., 2019. High genetic diversity and low differentiation retained in the european fragmented and declining Greater spotted eagle (Clanga clanga) population. Scientific Reports. 9, 1-11. https://doi. org/10.1038/s41598-019-39187-1

Wainwright, B.J., Arlyza, I.S., Karl, S.A., 2013. Isolation and characterization of nineteen microsatellite loci for the collector sea urchin, Tripneustes gratilla. Conservation Genetic Resources. 5, 939-941. https://doi.org/10.1007/ s12686-012-9683-9

Wainwright, B.J., Arlyza, I.S., Karl, S.A., 2019. Population genetics of the collector urchin, Tripneustes gratilla, in the Indonesian archipelago. Marine Ecology. 39, e12530. https://doi.org/10.1111/maec.12530

Wallace, C.C., Turak, E., DeVantier, L., 2011. Novel characters in a conservative coral genus: three new species of Astreopora (Scleractinia: Acroporidae) from West Papua. Journal of Natural History 45, 1905-1924. https://doi.org/10.1080/00222933.2011.573098

Walsh, P.S., Metzger, D.A., Higuchi, R., 2018. Chelex 100 as a medium for simple extraction of DNA for PCR-based typing from forensic material. Biotechniques, 54, 134139. https://doi.org/10.2144/000114018

WoRMS Editorial Board., 2020. World Register of Marine Species. Available at: http://www.marinespecies.org. [Date accessed: 9 November 2020] 